\title{
Do We Need a Theory of Externalization?
}

\author{
Roger Strange \\ Centre for International Business \& Development \\ University of Sussex \\ e-mail: R.N.Strange@sussex.ac.uk \\ Chapter prepared for \\ Research Agenda in International Business and Management \\ Edited by Ödül Bozkurt \& Mike Geppert
}

\begin{abstract}
:
Recent years have witnessed the proliferation of factoryless goods producers (FGPs) in the contemporary global economy. In this chapter, we outline a theory of externalization to explain not only the existence of factoryless goods producers, but also their ability to exert effective control over the activities throughout their organizationally-fragmented global value chains (GVCs). We stress the key role played by isolating mechanisms both in providing this control and in conferring upon the FGPs the power to determine the distribution of the value created within their GVCs.
\end{abstract}

Keywords: externalization; internalization; global value chains; factoryless goods producers

\section{Acknowledgement:}

I would like to thank Ödül Bozkurt, Mike Geppert, Irena Surdu and the participants at the March 2020 Paper Development Workshop in Jena for helpful comments on an earlier draft of this chapter. The usual disclaimer applies. 


\section{Do We Need a Theory of Externalization?}

\section{Introduction}

Recent years have witnessed the proliferation of factoryless goods producers (FGPs) in the contemporary global economy (Bernard \& Fort, 2015; Bayard et al, 2015; Morikawa, 2016; Fontagné \& Harrison, 2017; Kamal, 2018; Coyle \& Nguyen, 2019). Such FGPs have externalized (outsourced) the production activities within their global value chains (GVCs) to independent contract manufacturers ${ }^{1}$. Typically, such FGPs only undertake selected preproduction (e.g. design, R\&D, engineering) and/or post-production (e.g. sales, marketing, distribution) activities. Notable examples include Apple (Dedrick et al, 2010; Denicolai et al, 2015), Dyson (Bernard \& Fort, 2015), Nike (Donaghu \& Barff, 1990), Nokia (Ali-Yrkkö et al, 2011) and Uniqlo (Usui et al, 2017), but there is evidence of the substantial externalization of production activities to contract manufacturers worldwide across a range of industrial sectors including garments, footwear, toys, electronics, pharmaceuticals, automotive, and footwear. UNCTAD (2011: 133) estimated that contract manufacturing activities employed more than 13 million workers worldwide in 2010, mostly in emerging and developing economies. These activities generated more than $\$ 750 \mathrm{bn}$ sales $^{2}$.

Aggregate data on the scale of the FGP phenomenon are piecemeal, for reasons which will be discussed later in this paper. Some authors have attempted to provide estimates for individual countries, though these are typically partial and dated. Bernard \& Fort (2015: 521) estimated that the number of FGPs in the United States was 13,500 in 2007, and that these FGPs employed over 672,000 workers. Important sectors were pharmaceuticals, apparel and electronics. Furthermore, the importance of FGPs had risen substantially since 1992 when the corresponding figures were 4,900 firms and 285,000 workers. The number of FGPs rose further to 16,500 by 2016 (Kamal, 2018). Morikawa (2016) reports that there were 2,688 FGPs in Japan in 2013, employing over 1.1 million workers. Coyle \& Nguyen (2019) estimate that $1 \mathrm{~m}$ people were employed by FGPs in the UK in 2016. Important sectors were chemicals and pharmaceuticals, biotechnology, and electronics.

The aggregate data above focus on employment within the FGPs, but the influence of FGPs is much broader and more geographically-dispersed. The scope and nature of the FGP

\footnotetext{
${ }^{1}$ See Coyle \& Nguyen (2019: 5-7) for a discussion of alternative definitions of FGPs.

${ }^{2}$ Aggregate data on contract manufacturing are not readily available, and UNCTAD (2011) provides the most recent estimates for 2010. It should be stressed that the data are estimates - see UNCTAD (2011: 131) for the methodology - but are likely to underestimate the size of the contract manufacturing phenomenon.
} 
business model is well illustrated by the case of the US footwear and apparel firm, Nike. In November 2019, Nike employed 76,700 employees worldwide mostly in product design and development, marketing, distribution and sales. Nike has for many years outsourced the production of its footwear and other goods to contract manufacturers: this production was undertaken in 533 factories located in 41 countries and employing $1.16 \mathrm{~m}$, with materials provided by another 78 facilities in 11 countries $^{3}$. Many of the factories are located in Vietnam, China \& Indonesia, and no single factory accounts for more than $10 \%$ of total Nike output. The finished products are shipped to 6 US and 67 distribution centres worldwide, and thence to retailers. Three points are worth emphasizing at this stage: many more people are employed in the Nike GVC than are employed directly by Nike itself; the raw material and labour costs involved in the production of Nike footwear typically account for less than $50 \%$ of the retail price (Bissel-Linsk, 2017); and Nike's major suppliers also do business with other shoe and apparel makers, including New Balance, Adidas, and Puma.

The objective of this chapter is to provide a theoretical explanation for the existence of FGPs as organizational forms where lead firms (Apple, Dyson, Nike, Nokia etc) have externalized the production activities within their $\mathrm{GVCs}^{4}$, yet are still able to exert control over these production activities without direct ownership. Control is the key issue. Internalization theory provides a compelling explanation for the conditions under which it will be optimal for lead firms to bring geographically-dispersed GVC activities under common ownership |(and hence control), and hence for the existence of the integrated multinational enterprise (MNE). Internalization theory would predict that FGPs will exist when it is more efficient for lead firms to outsource the production activities to contract manufacturers and to coordinate these activities through arm's length contractual arrangements which specify the obligations of each party. Such legal contracts do provide a degree of control, but also suffer from a number of well-recognised shortcomings that limit their efficacy. First, contracts are, by nature, incomplete (Grossman \& Hart, 1996) and cannot cover all possible future contingencies, including the contract manufacturer developing and selling "similar" products to other buyers. Second, contracts for know-how and other intangible assets suffer from moral hazard in that, once provided by the FGP, the know-how cannot be "unlearned" by the contract manufacturer.

\footnotetext{
${ }^{3}$ This information is provided by Nike at www.manufacturingmap.nikeinc.com and related to November 2019. The information on direct employment at Nike is from https://www.statista.com/statistics/243199/number-ofemployees-of-nike-worldwide/

${ }^{4}$ We use the term "lead firm" to refer to firms which have outsourced significant activities within their GVCs to independent partners. Various synonymous terms are used in the literature, including inter alia flagship firm, hub firm, focal firm, orchestrator, network orchestrator, joint value orchestrator, strategic centre, strategic nexus, metaintegrator, and principal.
} 
Contract manufacturers may only respect and renew the contracts with their FGPs if the ongoing benefits arising from the relationship outweigh the potential benefits of selling their output to alternative customers. Third, many contract manufacturers are hosted by countries where the legal enforceability of contracts is weak (Zhou \& Poppo, 2010; World Justice Project, 2019; World Bank, 2020). A contract is only as effective as the legal institutions that support the effective implementation of contract law.

In this chapter, we advance a theory of externalization that explains how FGPs are able to reap the efficiency benefits of outsourcing their production activities whilst at the same time maintaining tight control over their organizationally-fragmented GVCs through the possession of key isolating mechanisms (Rumelt, 1984; 1987). Such mechanisms may take many forms including inter alia formal property rights, firm-specific technical and/or marketing capabilities, and multinationality. We outline this theory of externalization in the next section, before going on to consider some of the conceptual and practical implications of the growing FGP phenomenon.

\section{A Theory of Externalization}

Any production process may be depicted schematically as a value chain linking the inputs to the delivery of the final output to the customer - see Figure 1. The lead firms typically purchase raw materials, parts and components from independent suppliers, which they combine with their own distinctive intangible assets in product design, process engineering, $R \& D$, and technological know-how. These pre-production activities feed into a range of production activities that generate a series of intermediate goods and/or services that are subsequently assembled into the finished manufactured products. These products are then branded, promoted, sold and distributed to the final customers as part of the post-production activities, after which firms often provide a range of after-sales services (e.g. systems integration, maintenance, training, accessory sales) as part of what has been termed the servitization of business (Vandermerwe \& Rada, 1988). Value is created at each stage in this process, though how much value is created by each activity and by whom it is captured are issues to which we return below. These activities may all be located in one country, but often the activities are located in different countries hence the value chains are GVCs.

$$
* * * * * \text { Figure } 1 \text { about here } * * * * *
$$

Now there are many good reasons why firms might choose to integrate these preproduction, production, and post-production activities under common ownership. Vertical integration may inter alia improve scheduling and coordination; eliminate imperfect 
competition in upstream markets; facilitate investments in specialized assets, so protecting product quality and proprietary technology and avoiding opportunistic recontracting; allow price discrimination; and increase bargaining power vis-à-vis buyers and suppliers (Strange \& Magnani, 2018). The benefits of the cross-border integration of GVCs have typically been explored though the lens of internalization theory (Buckley \& Casson, 1976; Rugman, 1981; Hennart, 1982). Internalization theory highlights the relative costs and benefits of coordinating geographically-dispersed activities within GVCs internally by the management of a firm rather than externally through the market, and provides a parsimonious explanation for the existence of MNEs as the most efficient governance solution ${ }^{5}$.

The internalization of GVC activities also provides direct control not only over the activities, but also over the associated flows of knowledge. But the GVCs of many manufactured products are not fully integrated ${ }^{6}$. In case of FGPs, all the production activities are externalized to one or more contract manufacturers - see Figure 2 - who may be located in the same country, or overseas. The contract manufacturers purchase raw materials, parts and components from independent suppliers, and transform them into finished products using proprietorial designs, specifications and possibly technological know-how provided by their FGP. In return, the FGP pays a processing $\mathrm{fee}^{7}$ to their contract manufacturers to compensate them for their purchases of tangible inputs and the remuneration of their employees, and takes ownership of the finished goods. The FGP then brands, promotes, sells and distributes the product to the final customers. The GVCs thus involve intra-firm flows not only of physical products, but also flows of finance and of intellectual property embodied in intangible assets.

$$
* * * * * \text { Figure } 2 \text { about here } * * * * * *
$$

An internalization theory of FGPs might simply conclude that conditions must now be such that a market-based mechanism (i.e. the externalization of the production activities) is more efficient than a hierarchical solution (the MNE). The extant literature has highlighted

\footnotetext{
${ }^{5}$ See Nardella et al (2020) for a further perspective on the strengths and weaknesses of internalization theory, and its underpinning assumptions.

${ }^{6}$ The United Nations Economic Commission for Europe (UNECE) identify a number of "alternative production arrangements" that contrast with the vertically-integrated model of the MNE. First, there are "factoryless goods producers" (FGPs), which are discussed at length below. Second, there is the "transformation of goods owned by a domestic principal" in which the principal (lead firm) purchases (some of) the raw materials, parts and components, and sends these inputs to a contractor (often overseas) to be transformed into a final product. The lead firm maintains ownership of the raw materials etc throughout the transformation process and has ownership of the final product after processing. In contrast, FGPs do not buy or have ownership of the raw materials etc, and simply take ownership of the final product received from the contract manufacturer. Third, a "goods under merchanting" arrangement involves the supplier not only providing the raw materials etc, but also the intangible assets. The lead firm is simply a trader who takes ownership of the final product, and handles the marketing and distribution. See UNECE (2015) for further details.

${ }^{7}$ This processing fee will exclude the value of the intangible inputs provided by the FGP.
} 
various explanations for why and how FGPs may favour outsourcing to reduce production costs relative to the costs of undertaking activities in-house (Strange \& Magnani, 2018). One popular explanation is that FGPs externalize activities in order to focus on their core competencies, and thus economize on their scarce financial and managerial resources. Such core competencies represent the collective learning in the FGP, especially how to integrate multiple streams of technological and managerial competencies to enable individual firms to adapt quickly to changing opportunities, and form the basis of competitive advantage. There are, however, both conceptual and practical difficulties in actually specifying which activities are core (and thus should be internalized) and which activities are non-core (and thus may be usefully externalized). A second popular argument highlights the exploitation of learning opportunities and knowledge complementarities resulting from integration with independent agents in intermediate markets, in what has been termed strategic outsourcing. The emphasis is on the maximization of value generated in the value chain, instead of on the minimization of transaction costs. The FGPs not only seek direct cost benefits but also explore alternative solutions for securing higher value and innovative outcomes. In addition, a range of other rationales have been advance for outsourcing, including inter alia the FGPs having greater flexibility in response to volatile output demand and/or technology changes; reduced investment in plant and equipment; being able to benefit from the specialized skills and/or economies of scale enjoyed by outside suppliers; suppliers having lower labour and/or other production costs; and access to better quality inputs due to competition between outside suppliers. These explanations all hint at potential efficiency benefits from the externalization by FGPs of productive activities to contract manufacturers.

But internalization theory suggests that FGPs also relinquish control when they externalize their production activities. The FGPs will clearly have negotiated legal contracts with their contract manufacturers, and these contracts will specify the obligations of each party (including required outputs, payments etc), time periods, and sanctions for non-compliance. But legal contracts only provide a degree of control, for the reasons cited above: contracts are incomplete and do not cover all possible future contingencies; contracts for know-how and other intangible assets suffer from moral hazard; and the legal enforceability of contracts is weak in many countries. Thus, legal contracts are unlikely to provide FGPs with a sufficient level of control over their contract manufacturers. Hence, we argue that a theory of externalization is required which explains how FGPs are simultaneously able to externalize their production activities whilst maintaining direct behaviour control over their contract manufacturers (Strange \& Humphrey, 2019). This theory has two elements. The first element 
explains how and why FGPs possess power asymmetries over their contract manufacturers, and are able to leverage this power both to exert control over the externalized activities and to determine the distribution of the value created within the entire GVC. Such power asymmetries are a necessary condition for the existence of FGPs, but will only sustain a competitive advantage if there are ex post limits on their acquisition and/or imitation by the contract manufacturers and potential competitors (Mansfield et al, 1981; Ghemawat, 1986). These limits are provided by the possession of isolating mechanisms (Rumelt, 1984, 1987) ${ }^{8}$. The second element of the theory of externalization thus considers various possible isolating mechanisms that FGPs can employ to assure their long-term dominance over their contract manufacturers.

We first consider how and why FGPs possess power asymmetries over their contract manufacturers ${ }^{9}$. Drawing upon resource dependency theory (Cook, 1977; Pfeffer \& Salancik, 1978; Pfeffer, 1981; Cook \& Emerson, 1984; Ulrich \& Barney, 1984), we suggest that limitations on the availability of resources and capabilities foster specialization and necessitate organizational interdependence, and thus create resource dependencies, between lead firms and their GVC partners. Power derives from these dependencies: the more power enjoyed by one party, the more influence it has to determine the nature of the exchange relationship. Each party will try to alter the balance in its dependence relationships by acquiring control over resources and capabilities that either maximizes the other party's dependence on itself, and/or minimizes its own dependence on the other party. When a lead firm and its partners all possess scarce resources and capabilities, there is a power balance and the parties are interdependent. Alternatively, if neither the lead firm nor its partners possess scarce resources and capabilities then neither party enjoys a power advantage. In the typical FGP-contract manufacturer relationship (see Figure 2), however, the FGP is providing scarce and valuable intangible assets in the form of product designs, process engineering, R\&D and/or technological know-how whilst the contract manufacturers are offering routine and widely-available manufacturing and assembly operations. The FGPs possess scarce resources and capabilities not enjoyed by their contract manufacturers, the contract manufacturers are in the position of dependence, and the FGPs are able to leverage their power to exert control over the externalized production activities within their GVCs even in the absence of direct ownership.

\footnotetext{
${ }^{8}$ Isolating mechanisms at the firm-level are analogous to barriers to entry at the industry-level. Barney (1991) notes that effective isolating mechanisms rely on path dependence, causal ambiguity and/or social complexity. ${ }^{9}$ See Strange (2011) for a more extensive discussion.
} 
Why do the contract manufacturers not circumvent their subordinate relationships with their FGPs by selling the final products direct to the customers? After all, they have been provided with all the requisite designs, specifications and technological know-how to manufacture the products by their FGPs, and they themselves clearly have the necessary manufacturing resources and capabilities. The second element of our theory of externalization thus considers possible isolating mechanisms that FGPs can employ to hinder imitation of their valuable resources and capabilities, and hence sustain over time their positions of power over their contract manufacturers ${ }^{10}$.

The extant literature has identified several potential isolating mechanisms. Lawson et al (2012) provide a helpful categorization. Their first category relates to firm-specific technical knowledge, particularly when such knowledge is tacit and/or complex and/or developed though cumulative experience and learning, and is hence difficult for potential competitors to imitate. The second category relates to mechanisms to protect the knowledge embodied in products and/or processes, either by a reduction in the likelihood of knowledge leakage or through formal property rights allocated by the State (e.g. patents, trademarks, licenses). The third category relates to the first-mover advantages (Lieberman \& Montgomery, 1998) associated with being first to the market and thus in a position, as Lawson et al (2012: 422) emphasize, to 'gain pre-emptive access to geographic space, technological space, and customer perceptual space.' And the fourth category stresses the roles of market-based firm-specific assets such as corporate reputations and brand names, marketing capabilities, and distribution channels. Strong brand names and corporate reputations differentiate the firm's products from those of competitors, enhance customer switching costs and promote consumer 'lock-in' (Farrell, 2007), and act as proxies for quality, making it more difficult and expensive for potential competitors to imitate. Marketing capabilities allow firms to anticipate market trends and to offer benefits to consumers that are hard for competitors to imitate (Srivastava et al, 1998). Effective distribution channels are a vital channel for managing the seller-buyer interface (Day, 1994).

We would add three other potential isolating mechanisms. A fifth category should highlight the capability to collect and evaluate "big data" about emerging trends and opportunities in multiple markets in real-time (Strange \& Zucchella, 2018). The possession of

\footnotetext{
${ }^{10}$ The efficacy of many isolating mechanisms may also tend to dissipate over time as rivals emerge to imitate successful products and strategies, and as capability and resource asymmetries erode (Denicolai et al, 2015). A similar view is expressed by Le Breton-Miller \& Miller (2015: 397) who comment that "scholars have focused on the properties of resources and the isolating mechanisms that sustain their rents in the face of competition. Unfortunately, they have devoted far less attention to the sources of vulnerability of many of these resources."
} 
such a capability will require considerable investment in a range of technical, analytical and governance skills to realize the potential benefits in terms of value creation: large FGPs should have the financial wherewithal to develop such a capability, but the outlay will typically be beyond small contract manufacturers. A sixth category would focus on the geographic scope of the FGP (Kim, 2013; 2016). FGPs are typically multinational enterprises that undertake activities, including knowledge creation and market research activities, in many different countries. These different national environments drive FGPs to develop a range of heterogeneous resources and capabilities, which are not directly available to contract manufacturers confined to single countries. Furthermore, these heterogeneous resources and capabilities may result from firm-specific combinations of activities undertaken in different countries (Kafouros et al, 2018). Contract manufacturers may find it difficult even to acquire these resources and capabilities indirectly because of uncertainty and causal ambiguity. A seventh and final category focuses on the range of activities provided to the customers as part of the servitized offering than accompanies the manufactured products of many firms (Vandermerwe \& Rada, 1988; Sánchez-Montesinos et al, 2018). Providing such services to customers in multiple markets is a complex undertaking, made more difficult by cultural, geographic and other dimensions of distance.

Our suggested theory of externalization thus highlights that FGPs need to enjoy power asymmetries over their contract manufacturers if they are to maintain control over the production activities in their GVCs in the absence of direct ownership (internalization), that those asymmetries are founded on the FGPs' possession of valuable and scarce resources and/or capabilities, and that the scarcity of these resources and capabilities depends upon the FGPs developing effective isolating mechanisms. The greater the potency of the protection provided to FGPs by possession of some/all of these various isolating mechanisms, and the less their contract manufacturers enjoy such mechanisms, the more able will FGPs be to externalize activities and yet capture the rents within their GVCs. FGPs exist because they meet these conditions and are thus able both to externalize production activities and, moreover, to determine the distribution of the value created throughout their entire GVCs. Table 1 provides a succinct comparison of internalization theory and externalization theory.

$* * * * *$ Table 1 about here $* * * * *$

\section{Implications of the Growth of Factoryless Goods Producers}

The proliferation of FGPs worldwide is more than just a matter requiring theoretical explanation: it has a number of important conceptual, statistical, and policy implications. The 
first issue concerns the definition of the "firm". A legal definition would focus on the ownership of assets. However, given the degree of control that FGPs have over their contract manufacturers, perhaps a more meaningful definition might also embrace the latters' activities. Similar views have previously been expressed by Stephen Hymer (Strange \& Newton, 2006), by John Dunning \& Sarianna Lundan (2008), and by Keith Cowling \& Roger Sugden (1998: 67) who conceived the modern corporation as "the means of coordinating production from one centre of decision-making." It is also feasible that some FGPs may undertake all their preproduction and post-production activities in their domestic economies, whilst their contract manufacturers and their suppliers are all located overseas. In such cases, should the FGPs be defined as MNEs or simply as domestic firms?

A second issue is the definition of a "manufacturing firm". According to Revision 4 of the International Standard Industrial Classification (ISIC), a lead firm should be classified as a manufacturer only if it purchased some of the raw materials, parts and components (the tangible inputs) from the suppliers and provided them to the contract manufacturers. But the FGPs (as depicted in Figure 2) do not purchase any of these tangible inputs, hence should be classified as traders of goods under ISIC Section G (wholesale and retail trade) (UNECE, 2015). Yet FGPs sell manufactured products that typically they have designed and marketed under their brand names, and there have been ongoing discussions in various fora about the appropriate industrial classification of FGPs ${ }^{11}$. If FGPs are classified as manufacturing firms, then domestic manufacturing output (and employment) will appear higher than if they are classified as traders - and politicians and policy-makers may draw different conclusions about the health of domestic manufacturing industry - whilst the recorded output (and employment) in domestic services would fall. The issue is more than just semantics, as various commentators have acknowledged. For instance, Coyle \& Nguyen (2019) comment that "factoryless manufacturing is an increasingly significant phenomenon. It is important to start collecting relevant statistics if the dynamics of production in modern economies are to be understood, and for sector-based policies to be appropriately designed and targeted." Whitefoot et al (2015) suggest that policies and initiatives to promote manufacturing should take a value-chain perspective that also embraces pre-production and post-production activities. Levinson (2017)

\footnotetext{
${ }^{11}$ Factoryless goods manufacturing was first identified as a significant phenomenon in 2008. In 2010, the Economic Classification Policy Committee (ECPC) of the US Office of Management and Budget (OMB) recommended that from 2017 all FGPs should be re-classified to the manufacturing sector. This proposal was later withdrawn pending further research work. See Coyle \& Nguyen (2019) and UNECE (2015) for further details. UNECE (2015) note that FGPs have quite different production functions and cost structures to traditional vertically-integrated manufacturing firms, and hence recommend that they be treated and analyzed separately in the national accounts and in input-output tables.
} 
notes that "changes in the structure of manufacturing make it difficult to design government policies that support manufacturing-related value added and employment."

The third issue relates to the recording and interpretation of the inputs and outputs of FGPs in international trade statistics (UNECE, 2015; Linsi \& Mügge, 2019). FGPs, and more generally the growth of production organized in GVCs, have stimulated international trade in intermediate goods and services to the extent that it accounts for more than $60 \%$ of total trade. This had led the OECD and the WTO to undertake work on measuring trade in value-added (TiVA), and to the publication of the World Input-Output Database (UNECE, 2015). The basic issues are neatly illustrated in the celebrated analysis of the trade implications of 2010 Apple iPhone $3 G$ production (Xing \& Detert, 2010) ${ }^{12}$. Apple is a typical FGP which has externalized the production activities for most of its electronic products, including the iPhone. It is a US firm, which undertakes most of its product design, $R \& D$ and branding activities in the United States. The parts and components for the iPhone $3 \mathrm{G}$ were sourced from various suppliers (including Toshiba, Samsung, Infineon, Broadcom etc) located primarily in Japan, Korea, Germany, the United States and shipped to the Taiwanese contract manufacturer, Foxconn, for assembly in the People's Republic of China (PRC). Foxconn exported 11.3m finished iPhones to the United States in 2009 for subsequent distribution and sale at a retail price of $\$ 500$. The unit ex-factory cost of these iPhone was $\$ 179$, of which $\$ 60.60$ was paid to Japanese suppliers, $\$ 30.15$ to German suppliers, $£ 22.96$ to Korean suppliers, $\$ 10.75$ to US suppliers, and $\$ 48.04$ to suppliers elsewhere - see Figure 3. The unit assembly cost in the PRC was a mere $\$ 6.50$. The total value of the iPhones exported to the United States in 2009 was thus $\$ 2022.7 \mathrm{~m}$, and the recorded net US bilateral deficit with China was $\$ 1901.2 \mathrm{~m}^{13}$. But this substantial trade deficit on finished iPhones included imported parts and components from Japan etc worth $\$ 1827.8 \mathrm{~m}$. In value-added trade statistics, the bilateral US trade deficit with China falls to just $\$ 73.4 \mathrm{~m}$ (i.e. the cost of assembly of the $11.3 \mathrm{~m}$ iPhones). The iPhone is just one product, but the example provides a clear example of how conventional international trade statistics can be misleading when FGPs have externalized their production activities to contract manufacturers located overseas. One suggested alternative treatment (Bayard et al, 2015) would be to register the final products of FGPs as outputs in their domestic economies (i.e. Apple products would be registered as US products) using services provided by their (overseas) contract

\footnotetext{
${ }^{12}$ Professor Xing has since updated the analysis to examine the trade implications of iPhone X production in 2018 (Xing, 2019).

${ }^{13}$ This trade deficit related to iPhone production, together with the aggregate US bilateral trade deficit with the PRC, has been the subject of considerable disquiet for successive US Presidents including Barack Obama and Donald Trump.
} 
manufacturers. This would result in lower recorded imports of goods, a concomitant rise in the recorded imports of services, but no change in the overall balance on trade. Some commentators see this as preferable to the existing treatment in conventional trade statistics, but critics point out that it would overstate the health of domestic manufacturing industry. Furthermore, and more perversely, goods produced overseas by contract manufacturers and sold directly to customers in third countries would be recorded as exports from the FGP's domestic economy even if they had never physically entered the domestic economy ${ }^{14}$.

$$
* * * * * \text { Figure } 3 \text { about here } * * * * *
$$

The fourth issue concerns the extent to which FGPs not only externalize their production activities, but are able to externalize responsibility for employee remuneration and working conditions at their contract manufacturers (Strange, 2011; Burmester et al, 2019; Balcet \& Ietto-Gillies, 2020; Dörrenbächer \& Ellermann, 2020) and for environmental problems (e.g. pollution, carbon emissions) within their GVCs? Thankfully, there are signs that FGPs (and other MNEs) are increasingly being held to account for the activities undertaken on their behalf by suppliers and contract manufacturers. As Strange \& Humphrey (2019: 1406) note, consumer and NGO pressures have obliged lead firms "to take responsibility for the labour and environmental impacts of their value chains, as discussed by van Tulder, van Wijk \& Kolk (2009) and many others. Campaigners for labor rights make the link between brand name companies such as Apple and the labor policies used by subcontractors, often pointing to how these conditions arise (directly or indirectly) from the way in which buyers pressure their suppliers to reduce costs and make rapid adjustments in production volumes. Therefore, the externalization of activities may leave a lead firm in the position where it does not have direct control over its suppliers' factories, but it is still held responsible to some extent for its suppliers' behaviour."

The fifth and final issue relates to the implications for the distribution of income worldwide over the past thirty years as a result of the global shifts in the location of production activities from the advanced economies to the emerging economies (Buckley \& Strange, 2015). These global shifts have arisen due to a combination of the growth of indigenous firms from the emerging economies, increased FDI by MNEs from the advanced economies, and the offshore outsourcing strategies of FGPs. In the latter case, many FGPs have externalized productive activities to contract manufacturers in offshore locations but have - as described above - still retained control over their geographically-dispersed and organizationally-

\footnotetext{
${ }^{14}$ See Chapter 7 of UNECE (2015) and Loungani et al (2017) for further discussion.
} 
fragmented GVCs. As a result, most of the value created in the GVCs is captured by the FGPs in advanced economies whilst the contract manufacturers in the emerging economies receive only a small proportion. This is clearly seen in the iPhone case provided above, where the income accruing to the manufacturers undertaking the assembly operations in PRC was only $1.3 \%$ (\$6.50 / \$500) of the retail price. The majority of the income (\$500 - \$179) accrues to Apple, and is dispersed to its employees and other stakeholders who are likely to be resident in the US and other advanced economies.

\section{Final Comments}

In this chapter we have outlined a theory of externalization to explain not only the existence of factoryless goods producers, but also their ability to exert effective control over the activities throughout their organizationally-fragmented GVCs. We have stressed the key role played by isolating mechanisms both in providing this control and in conferring upon the FGPs the power to determine the distribution of the value created within their GVCs. Various potential isolating mechanisms have been identified, including the capability for big data analytics, multinationality, and the provision of associated services.

We have also highlighted the empirical importance of FGPs in many countries, and the need to measure their activities so as to properly attribute them across sectors and countries and thus help countries formulate appropriate economic policies. These measurement efforts are ongoing in many national and international statistical organizations. In the meantime, attention might usefully be devoted to providing detailed in-depth case studies of the operations of FGPs and the evolution of their relationships with their contract manufacturers.

A final comment relates to the fact that most FGPs have clearly originated in more advanced economies, which raises the question of whether their genesis might depend upon particular institutional, economic and/or other characteristics of their home countries. Following Richard Langlois (2003), we suggest that the optimal balance between internalization and externalization depends upon the interplay between technology, institutions, and organization - and this balance depends on historical circumstances (Jones \& Khanna, 2006). Langlois notes that Adam Smith had predicted a finer division of labour between firms as markets grew, as a result of increases in population and per capita incomes coupled with reductions in barriers to trade and transportation costs. Smith suggested that this process would ceteris paribus lead to increased coordination through markets. But Langlois noted that the coordination needs of high-throughput technologies in the early decades of the twentieth century outweighed the abilities of contemporary institutions and markets to meet 
those needs, with the result that firms became (on average) more vertically integrated. The visible hand - to echo Alfred Chandler's famous work - of managerial coordination came to replace, at least in part, the invisible hand of the market. It is also worth noting that this was also the period during which large vertically-integrated MNEs came to dominate the global economy (Jones, 1993; Wilkins, 2001; Chandler \& Mazlish, 2005), and also the period that spawned the original contributions to internalization theory. More recently, the global markets for many goods and services have developed apace as new (emerging) countries have experienced high rates of economic growth and as institutions (both those within these countries, and those guiding the global trading system) have evolved to support market exchange. It is in this historical context that Langlois (2003) advanced his vanishing hand hypothesis to explain the growth of externalization. Such a perspective would also suggest that FGPs may soon become common in the more developed emerging economies.

\section{Bibliography}

Ali-Yrkkö, J., P. Rouvinen, T. Seppälä and P. Ylä-Antilla (2011), 'Who captures value in global supply chains? Case of Nokia N95 smartphone', Journal of Industry, Competition, and Trade, 11(3), 263-278.

Balcet, G. and G. Ietto-Gillies (2020), 'Internationalization, outsourcing and labour fragmentation: the case of FIAT', Cambridge Journal of Economics, 44(1), 105-128.

Barney, J. (1991), 'Firm resources and sustained competitive advantage', Journal of Management, 17(1), 99-120.

Bayard, K., D. Byrne and D. Smith (2015), 'The scope of US "factoryless manufacturing", in S.N. Houseman \& M.J. Mandel (eds.), Measuring globalization: better trade statistics for better policy, vol.2, pp.81-120. Kalamazoo MI: WE Upjohn Institute for Employment Research.

Bernard, A.B. and T.C. Fort (2015), 'Factoryless goods producing firms', American Economic Review: Papers \& Proceedings, 105(5), 518-523.

Bissell-Linsk, J. (2017), 'Nike's focus on robotics threatens Asia's low-cost workforce: developing countries at risk of losing cheap manufacturing if leisurewear companies accelerate automation.' Financial Times, 22 October.

Buckley, P.J. and M. Casson (1976), The future of the multinational enterprise. Basingstoke: Macmillan.

Buckley, P.J. and R. Strange (2015), 'The governance of the global factory: location and control of world economic activity', Academy of Management Perspectives, 29(2): 237249.

Burmester, B., S. Michailova and C. Stringer (2019), 'Modern slavery and international business scholarship: the governance nexus', Critical Perspectives on International Business, 15(2/3): 139-157.

Chandler Jr, A.D. and B. Mazlish (eds) (2005), Leviathans: multinational corporations and the new global history. Cambridge: Cambridge University Press.

Cook, K.S. (1977), 'Exchange and power in networks of interorganizational relations', Sociological Quarterly, 18(1): 62-82. 
Cook, K.S. and R. Emerson (1984), 'Exchange networks and the analysis of complex organizations', Sociology of Organizations, 3: 1-30.

Cowling, K. and R. Sugden (1998), 'The essence of the modern corporation: markets, strategic decision-making and the theory of the firm.' The Manchester School, 66(1): 59-86.

Coyle, D. and D. Nguyen (2019), 'No plant, no problem? Factoryless manufacturing and economic measurement.' National Institute of Economic and Social Research, Economic Statistics Centre of Excellence, ESCoE Discussion paper, no.2019-15.

Day, G.S. (1994), 'The capabilities of market-driven organizations.' Journal of Marketing, 58(4), 37-52.

Dedrick, J., K.L. Kraemer and G. Linden (2010), 'Who profits from innovation in global value chains? A study of the iPod and notebook PCs', Industrial and Corporate Change, 19(1), 81-116.

Denicolai, S., R. Strange and A. Zucchella (2015), 'The dynamics of the outsourcing relationship.' In R. van Tulder, A. Verbeke \& R. Drogendijk (eds.), Multinational enterprises and their organizational challenges, pp.341-364. Progress in international business research, volume 10. Bingley, UK: Emerald.

Donaghu, M.T. and R. Barff (1990), 'Nike just did it: international subcontracting and flexibility in athletic footwear production', Regional Studies, 24(6), 537-552.

Dörrenbächer, C. and L. Ellermann (2020), 'Developing parameters for the occurrence of modern slavery: towards an empirical validation of Crane's (2013) theory of modern slavery', this volume.

Dunning, J.H. and S.M. Lundan (2008), Multinational enterprises and the global economy. Second edition. Cheltenham: Edward Elgar.

Farrell, J. and P. Klemperer (2007), 'Coordination and lock-in: competition with switching costs and network effects', in M. Armstrong \& R. Porter (eds,), Handbook of industrial organization, pp.1967-2002. Amsterdam: Elsevier.

Fontagné, L. and A. Harrison (eds.) (2017), The factory-free economy: outsourcing, servitization, and the future of industry. Oxford: Oxford University Press.

Ghemawat, P. (1986), 'Sustainable advantage', Harvard Business Review, 64(5), 53-58.

Grossman, S.J. and O.D. Hart (1986), 'The costs and benefits of ownership: a theory of vertical and lateral integration', Journal of Political Economy, 94(4), 691-719.

Hennart, J-F. (1982), A theory of multinational enterprise. Ann Arbor: University of Michigan Press.

Jones, G. (1993), Transnational corporations: a historical perspective. London: Routledge.

Jones, G. and T. Khanna (2006), 'Bringing history (back) into international business', Journal of International Business Studies, 37(4), 453-468.

Kafouros, M., C. Wang, E. Mavroudi, J. Hong and C.S. Katsikeas (2018), 'Geographic dispersion and co-location in global $R \& D$ portfolios: consequences for firm performance', Research Policy, 47(7), 1243-1255.

Kamal, F. (2018), 'A portrait of US factoryless goods producers', National Bureau of Economic Research, Working paper no.25193.

Kim M. (2013), 'Many roads lead to Rome: implications of geographic scope as a source of isolating mechanisms', Journal of International Business Studies, 44(9), 898-921.

Kim, M. (2016), 'Geographic scope, isolating mechanisms, and value appropriation', Strategic Management Journal, 37(4), 695-713.

Langlois, R.N. (2003), 'The vanishing hand: the changing dynamics of industrial capitalism', Industrial and Corporate Change, 12(2), 351-385.

Lawson, B., D. Samson and S. Roden (2012), 'Appropriating the value from innovation: inimitability and the effectiveness of isolating mechanisms', $R \& D$ Management, 42(5), 420-434. 
Le Breton-Miller, I. and D. Miller (2015), 'The paradox of resource vulnerability: considerations for organizational curatorship', Strategic Management Journal, 36(3), 397-415.

Levinson, M. (2017), 'What is manufacturing? Why does the definition matter?' Washington, DC: Congressional Research Service, CRS Report R44755.

Linsi, L. and D.K. Mügge (2019), 'Globalization and the growing defects of international economic statistics', Review of International Political Economy, 26(3), 361-383.

Loungani, P., S. Mishra, C. Papageorgiou and K. Wang (2017), World trade in services: evidence from a new dataset, IMF Working Papers. Washington, DC: IMF.

Mansfield, E., M. Schwartz and S. Wagner (1981), 'Imitation costs and patents: an empirical study', Economic Journal, 91(364), 907-918.

Morikawa, M. (2016), 'Factoryless goods producers in Japan', Japan and the World Economy, 40, 9-15.

Nardella, G., R. Narula and I. Surdu (2020). 'Behavioural theory and MNE decision making: changing the narrative in international business management', this volume.

Pfeffer, J. (1981), Power in organizations, Marshfield MA: Pitman.

Pfeffer, J. and G. Salancik (1978), The external control of organizations: a resource dependence perspective, New York: Harper \& Row.

Sánchez-Montesinos, F., M. Opazo Basàez, D. Arias Aranda and O.F. Bustinza (2018), 'Creating isolating mechanisms through digital servitization: the case of Covirán', Strategic Change, 27(2), 121-128.

Rugman, A.M. (1981), Inside the multinationals: the economics of the multinational enterprise, New York: Columbia University Press.

Rumelt, R.P. (1984), 'Towards a strategic theory of the firm', in R. Lamb (ed.), Competitive strategic management, pp.566-570. Englewood Cliffs, NJ: Prentice Hall.

Rumelt, R.P. (1987), 'Theory, strategy and entrepreneurship' in D.J. Teece (ed.), The competitive challenge: strategies for industrial innovation and renewal, pp.137-158. Cambridge MA: Ballinger.

Srivastava, R.K., T.A. Shervani and L. Fahey (1998), 'Market-based assets and shareholder value: a framework for analysis', Journal of Marketing, 62(1), 2-18.

Strange, R. (2011), 'The outsourcing of primary activities: theoretical analysis and propositions', Journal of Management \& Governance, 15(2), 249-269.

Strange, R. and J. Humphrey (2019), 'What lies between market and hierarchy? Insights from internalization theory and global value chain theory', Journal of International Business Studies, 50(8), 1401-1413.

Strange, R. and G. Magnani (2018), 'Outsourcing, offshoring and the global factory', in G. Cook \& F. McDonald (eds.), The Routledge companion to the geography of international business, pp.60-77. Abingdon UK \& New York: Routledge.

Strange, R. and J. Newton (2006), 'Stephen Hymer and the externalization of production', International Business Review, 15(2), 180-193.

Strange, R. and A. Zucchella (2017), 'Industry 4.0, global value chains and international business', Multinational Business Review, 25(3), 174-184.

Vandermerwe, S. and J. Rada (1988), 'Servitization of business: adding value by adding services', European Management Journal, 6(4), 314-324.

Ulrich, D. and J.B. Barney (1984). 'Perspectives in organizations: resource dependence, efficiency, and population', Academy of Management Review, 9(3), 471-481.

UNCTAD (2011), World investment report 2011. Non-equity modes of international production and development, New York \& Geneva: UNCTAD.

UNECE (2015), Guide to measuring global production, New York \& Geneva: United Nations. 
Usui, T., M. Kotabe and J.Y. Murray (2017), 'A dynamic process of building global supply chain competence by new ventures: the case of Uniqlo', Journal of International Marketing, 25(3), 1-20.

van Tulder, R., J. van Wijk and A. Kolk (2009), 'From chain liability to chain responsibility', Journal of Business Ethics, 85(2 Supplement), 399-412.

Whitefoot, K.S., W.D. Valdivia \& G.C. Adam (2015), Innovation and manufacturing labour: a value-chain perspective, Washington DC: Brookings Center for Technology Innovation.

Wilkins, M. (2001), 'The history of multinational enterprise', In A.M. Rugman and T.L Brewer (eds.), The Oxford handbook of international business, pp.3-35. Oxford: Oxford University Press.

World Bank (2020), Doing business 2020: comparing business regulations in 190 economies, Washington DC: World Bank Group.

World Justice Project (2019), Rule of law index 2019, Washington DC: World Justice Project.

Xing, Y. (2019), 'How the iPhone widens the US trade deficit with China: the case of the iPhone X', Available at: https://voxeu.org/article/how-iphone-widens-us-trade-deficitchina-0

Xing, Y. and N. Detert (2010), 'How the iPhone widens the United States trade deficit with the People's Republic of China', Asian Development Bank Institute, Working Paper no.257.

Zhou, K.Z. \& L. Poppo (2010), 'Exchange hazards, relational reliability, and contracts in China: the contingent role of legal enforceability', Journal of International Business Studies, 41(5), 861-881. 


\section{Figure 1: A Typical Global Value Chain}

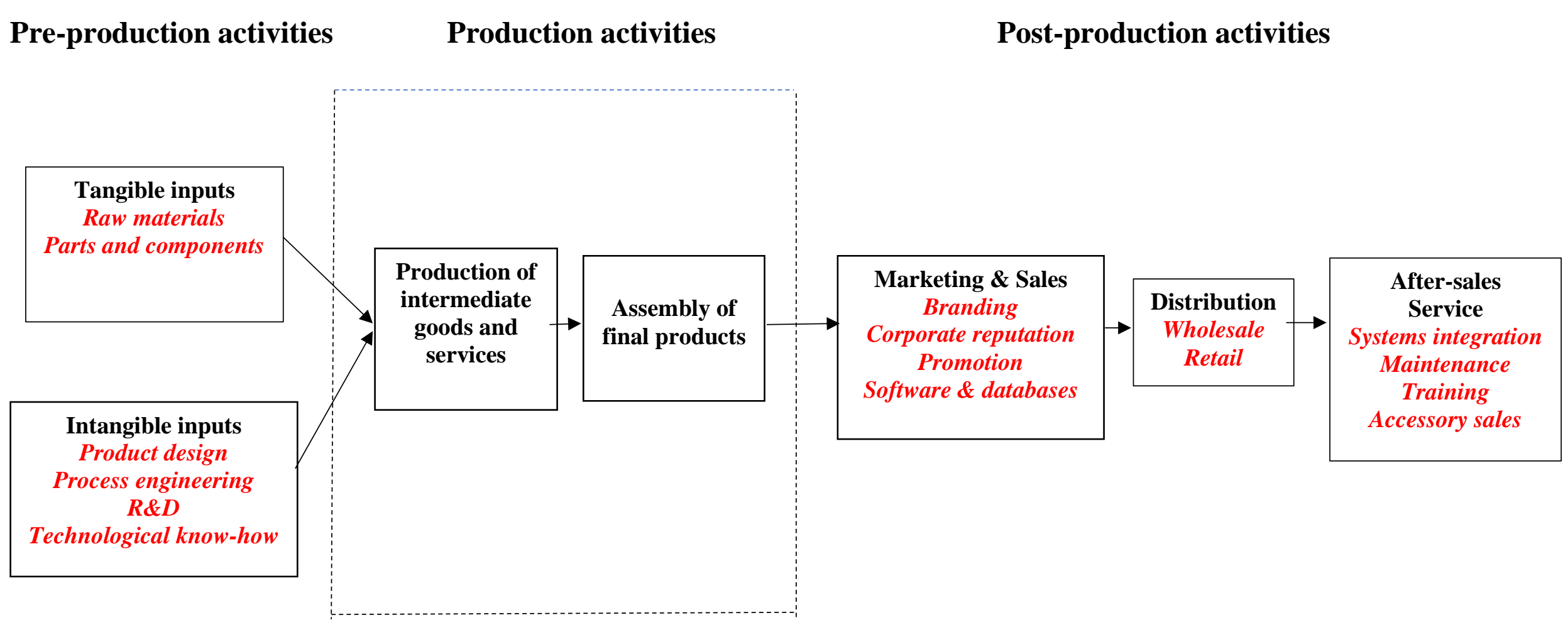




\section{Figure 2: The Global Value Chain of a Factoryless Goods Producer}

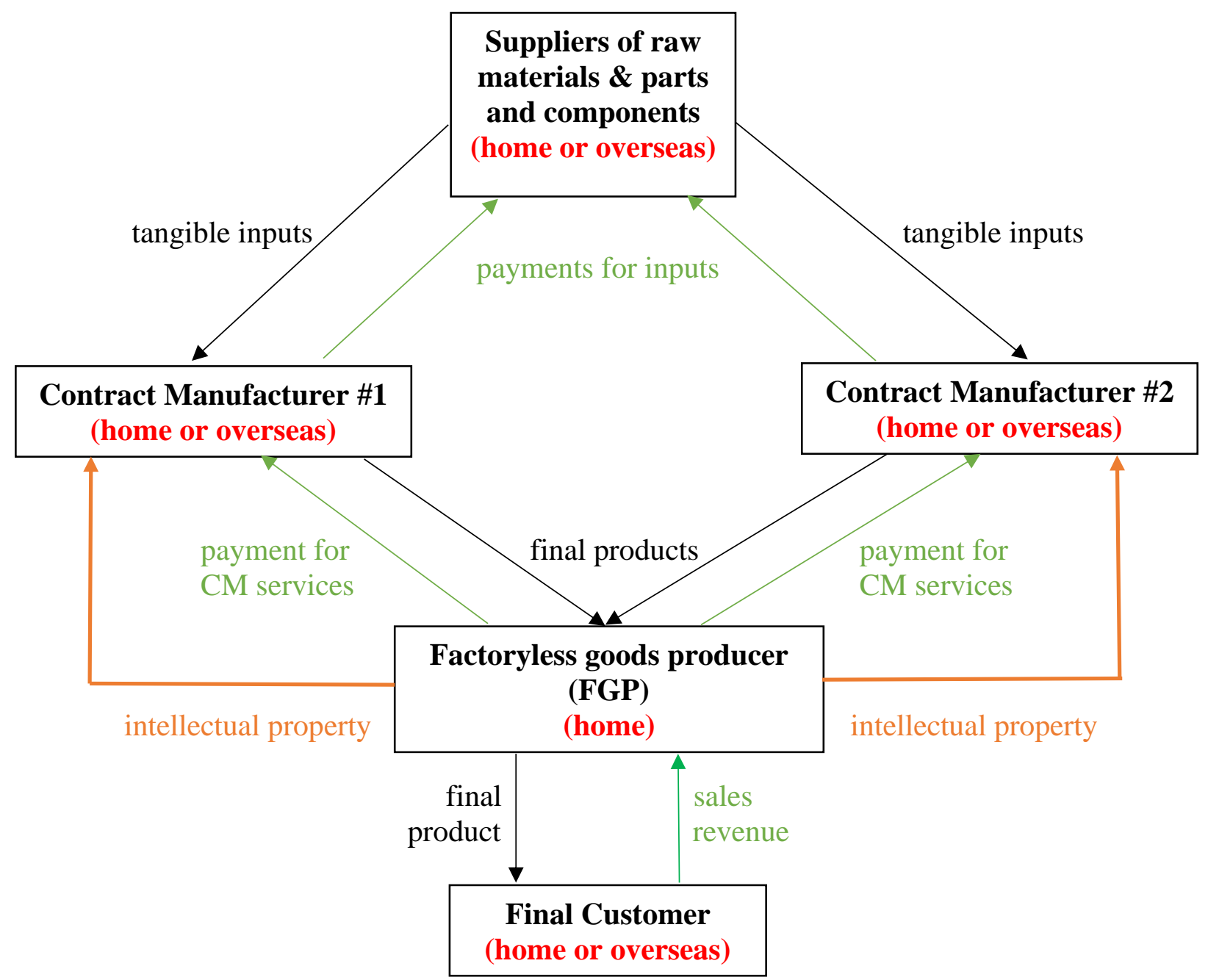

$\begin{array}{ll}\longrightarrow & \text { Flows of physical products } \\ \longrightarrow & \text { Flows of money } \\ & \text { Flows of intellectual property }\end{array}$ 
Figure 3: The Global Value Chain for the Apple iPhone 3G, 2009

Suppliers
Contract manufacturer
Factoryless Goods

Producer

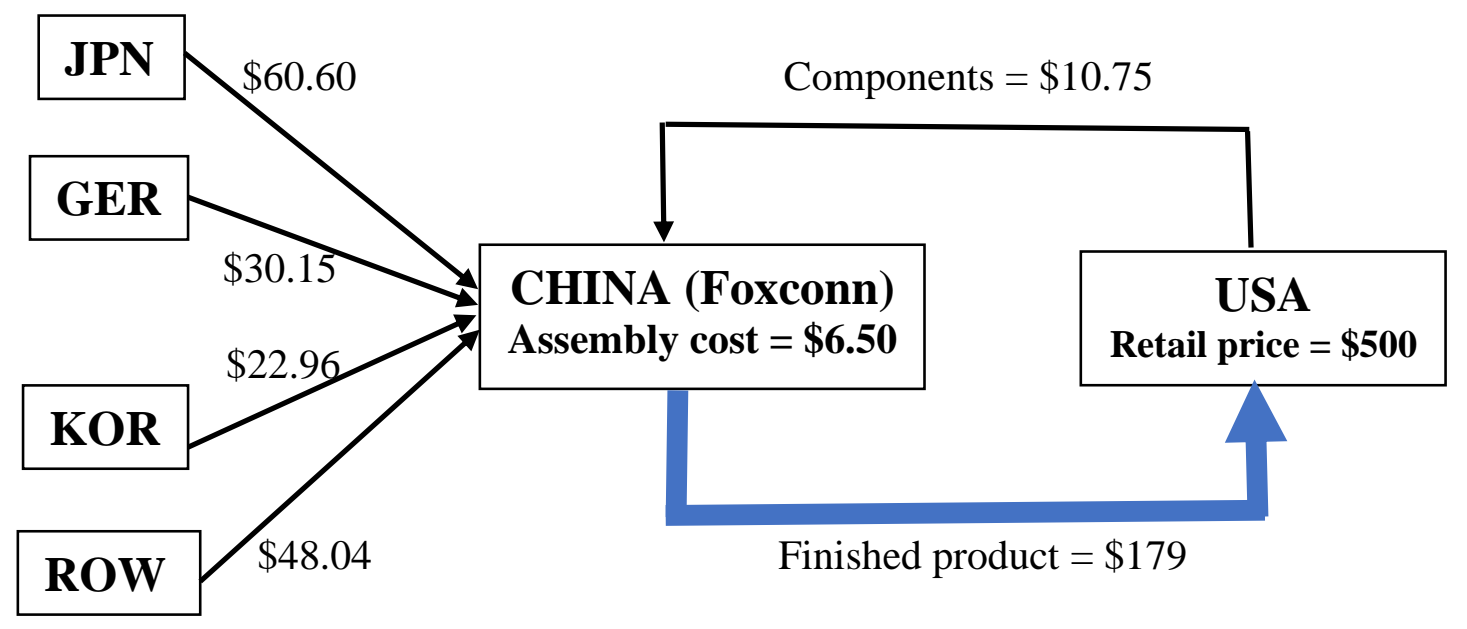

Notes:

- The monetary amounts shown are the unit costs for one iPhone

- Apple sold 11.3m iPhones in the USA in 2009

- The profit margin on one iPhone was $64 \%$ 


\section{Table 1: A Comparison of Internalization Theory and Externalization Theory (as applied to the production of goods)}

\begin{tabular}{|c|l|l|}
\hline \multicolumn{1}{|c|}{ Internalization Theory } & \multicolumn{1}{|c|}{ Externalization Theory } \\
\hline Main focus & \multicolumn{1}{|c|}{} \\
\hline Lead firms & $\begin{array}{l}\text { Why do lead firms internalize } \\
\text { GVC activities? }\end{array}$ & $\begin{array}{l}\text { How do lead firms coordinate } \\
\text { externalized GVC activities? }\end{array}$ \\
\hline $\begin{array}{c}\text { Who carries out the productive } \\
\text { activities? }\end{array}$ & Multinational enterprises (MNEs) & $\begin{array}{l}\text { Factoryless goods producers } \\
\text { (FGPs) }\end{array}$ \\
\hline $\begin{array}{c}\text { What is internalized? } \\
\text { Source of control by lead firms }\end{array}$ & $\begin{array}{l}\text { Internalization of operations \& } \\
\text { knowledge }\end{array}$ & $\begin{array}{l}\text { Externalization of operations } \\
\text { internalization of knowledge }\end{array}$ \\
\hline Mechanisms of control & Hierarchical control & $\begin{array}{l}\text { Control through asymmetric power } \\
\text { relations }\end{array}$ \\
\hline $\begin{array}{c}\text { Main source of competitive } \\
\text { advantage }\end{array}$ & $\begin{array}{l}\text { Efficient cross-border governance } \\
\text { arrangement }\end{array}$ & Isolating mechanisms \\
\hline $\begin{array}{c}\text { Industry classification of lead } \\
\text { firms }\end{array}$ & Manufacturing (ISIC Section D) & $\begin{array}{l}\text { Wholesale and retail trade (ISIC } \\
\text { Section G) }\end{array}$ \\
\hline
\end{tabular}

